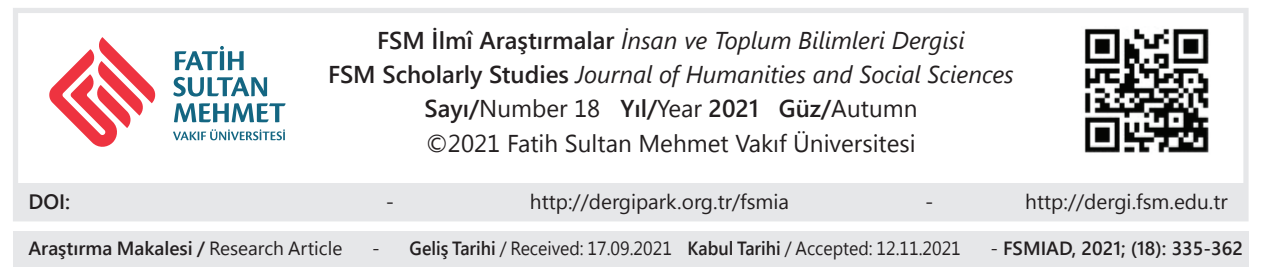

\title{
Demografik Değişkenlerin, Okul Öncesi Öğretmenlerinin Sınıf Yönetimi Becerileri Üzerine Etkilerinin Analizi
}

Baran Barış Yıldız

\section{$\ddot{O} z$}

$\mathrm{Bu}$ araştırmanın amacı; demografik değişkenlerin, okul öncesi öğretmenlerinin s1nıf yönetimi becerileri üzerine etkilerinin analizidir. Kuramsal kısımların yazımında tümdengelim ve uygulama kısmında nicel yöntemlerden, ilişkisel tarama modeli esas alınmıştır. Çalışmanın evreni İstanbul ili Avcılar ilçesinde resmi ilkokullarda okul öncesi eğitim kurumlarında çalışan öğretmenlerdir. Araştırmanın anketin birinci kısmında demografik bilgilerin elde edilmesine yönelik 4 madde ve öğretmenlerin sınıf yönetimi becerilerini ölçmeye yönelik 6 boyut 36 maddeden oluşan "Sınıf Yönetimi Ölçeği Öğ retmen Formu" yer almıştır. Yapılan analizler sonucunda; öğretmenlerin sınıf yönetimi becerilerinden; öğrenme-öğretme süreci ve davranış yönetimi becerisi ile katılımcıların öğrenim durumuna göre istatistiksel olarak anlamlı farklılık olduğu tespit edilmiştir. Ayrıca, ön lisans düzeyinde eğitim almış öğretmenlerin davranış yönetiminde daha düşük, öğrenme-öğretme süreçlerinde ise daha yüksek puan ortalamalarına sahip oldukları gözlemlenmiştir.

Anahtar Kelimeler: Eğitim-öğretim, sınıf yönetimi becerisi, öğretmen, kariyer oluşumu.

* Dr., İstanbul İl Milli Eğitim Müdürlüğü, İstanbul/Türkiye, bbaris_yildiz@windowslive.com, orcid.org/0000-0003-1247-3158. 


\title{
Analysis of the Effects of Demographic Variables on Preschool Teachers' Classroom Management Skills
}

\begin{abstract}
The purpose of this research; The analysis of the effects of demographic variables on the classroom management skills of preschool teachers. In the writing of the theoretical parts, the relational screening model is based on the deduction and the quantitative methods in the application part. The universe of the study is the teachers working in pre-school education institutions in public primary schools in Avc1lar district of Istanbul. In the first part of the survey, there was a "Classroom Management Scale Teacher Form" consisting of 4 items for obtaining demographic information and 6 dimensions and 36 items for measuring teachers' classroom management skills. As a result of the analyzes made; teachers' classroom management skills; It has been determined that there is a statistically significant difference according to the learning-teaching process and behavior management skills and the educational status of the participants. In addition, it has been observed that teachers with associate degree education have lower average scores in behavior management and higher mean scores in learning-teaching processes.
\end{abstract}

Keywords: Education and training, classroom management skills, teacher, career formation. 


\section{Giriş}

Bu çalışmanı amac1, demografik özelliklerin, okul öncesi öğretmenlerin s1nıf yönetimi becerileri üzerinde etkilerinin araştırılmasıdır. Eğitim ve öğretimin ana unsurlarından olan okulların; eğitim faaliyetlerinin gerçekleşmesinde, kariyer oluşumlarında, ve her meslekten vasıflı insan gücünün kazandırılmasında ve ülkelerin geleceği olan yeni nesillerin yetiştirilmesidir ${ }^{1}$. Yönetim ise; insanların çalıştırılması, iş yaptırabilme ve insanların iradelerini en iyi şekilde yönetebilme sanatı şeklinde tanımlanabilir². Bu kapsamda okul öncesi eğitim-öğretim faaliyetlerinin başarısında temel unsurlardan birisi sınıf yönetimdir. Sınıf yönetimi, öğrenci davranışlarının kontrol edilmesi, düzenli sistematik bilgilerin aktarılmas1 ve etkili öğrenme ortamının oluşturulması ile ilgili etkinlikleri kapsamaktadır. Etkili bir sınıf yönetimi için pedagojik bilgiler, meslek bilgiler ve alan bilgileri ön plana çıkmaktadır³. Bilginin uygulanabilmesinde ise becerili olunması yani görevlerin tamamlanabilmesi ve problemlerin çözülmesi gerekmektedir ${ }^{4}$. Beceriler; mantıksal, yaratıcı ve sezgisel olabileceği gibi materyal oluşturma becerisi, araç gereç kullanma, yöntem ve el becerisi şeklinde sıralanabilir ${ }^{5}$. Okul öncesi öğretmenlerin becerisi ise istendik davranışların kabullenmesine ve öğrencilerin başarısına etki etmektedir. Sınıf yönetimi başarısı ve öğrencileri en iyi şekilde yetiştirilebilmesi için sını içi etkinliklerin; hem öğretmenler hem öğrenciler tarafından benimsenerek, katılımcı bir anlayışla sürdürülmesi gerekmektedir ${ }^{6}$

Okul öncesi öğretmenlerinin sınıf yönetimi becerileri, çocukların en iyi şekilde yetişmelerinde önemli bir işlevi yerine getirmektedir. Öğrenci ise eğitim süreçleri kapsamında eğitim ve öğretim süreçlerini tamamen yaşayarak bu yaşantılar sonucunda bilgi ve deneyimlerini artıran kişiler olarak tanımlanmaktadır. Öğrenci olgusunun içeriğinde, yalnızca bilgilenen ya da öğrenen bir birey olma özelliği olmamakla birlikte, hayata hazırlanan ve çevresine katkı sunacak kişi olma özelliği de dikkate alınmalıdır . Öğrencilerin belirlenen amaçlara yönelik

1 E. Yeşilyurt - İ. Çankaya, "Sınıf Yönetimi Açısından Öğretmen Niteliklerinin Belirlenmesi”, Elektronik Sosyal Bilimler Dergisi, cilt 7, say1 23, 2008, s. 275.

2 Ö. Yüksel, Girişimciler Iç̧in Işsletme Yönetimi, Ankara, Gazi Yayınları, 2003, s. 56.

3 G. Paliç - E. Keleş, "Sınıf Yönetimine İlişkin Öğretmen Görüşleri”, Educational Administration: Theory and Practice, cilt 17, say1 2, 2011, s. 216.

4 M. Ç. Özdemir, Sınıf Yönetimi, Ankara, Pegem Atıf İndeksi, 2017, s. 2.

5 T.C. Yükseköğretim Kurulu, Türkiye Yükseköğretim Ulusal Yeterlikler Çerçevesi (TYUYÇ) : Ara Raporu, 2009, s. 8.

6 M. Erden, Sinıf Yönetimi, Ankara, Arkadaş Yayınevi, 2005, s. 199.

7 G. Topses, “Öğrenci Davranışlarını Etkileyen Psikolojik Etmenler ve Sorunlar”, Sınıf Yönetimi, (içinde), ed. Leyla Küçükahmet, 9. bs., Ankara, Nobel Yayın Dağıtım, 2007, s. 13. 
yetiştirilme süreçleri eğitim ve öğretim faaliyetlerinden geçmektedir. Eğitim sürecinde öğrencilerin kişilikleri; eğitim süreçlerinde kazanılan beceri, biçimlenen davranış, elde edilen değerler ve sağlanan bilgiden etkilenmektedir. Dolayısıyla sınıf yönetimi; yaşam süreçlerinin tamamını kapsamakta, çocukları hayata hazırlamakta ve kişiliklerini kazanmalarında çok büyük önem arz etmektedir8 Bu kapsamda araştırmanın problem cümlesi; demografik özelliklerin, okul öncesi öğretmenlerin sınıf yönetimi becerileri üzerinde etkisi var mıdır şeklinde oluşturulmuştur. Diğer bir anlatımla, bu çalışmada; öğretmenlerin öğrencilerine yönelik rol medol olabilecek tutumları, sınıf yönetimi yetkinlikleri, sınıf içinde çok yönlü (öğretmen-öğrenci, öğrenci-öğrenci) iletişim, sınıf içinde doğabilecek kaza ve tehlikelere karşı gerekli güvenlik önlemleri, tüm öğrencilere eşit ve adil davranılması, sınıf kurallarının öğrencilerle birlikte belirlenmesi, sınıftaki tüm öğrencilerin derse ve etkinliklere katılımının teşviki ve benzeri konularda incelemeler yapılmıştır.

\section{Kavramsal Çerçeve}

Okullar nitelikli insan gücünün yetiştirilmesinde önemli görevleri üstlenmektedir`. Bu kapsamda eğitim faaliyetlerinin başarılı olabilmesi de öğretmenlerin yetişmesine, okullardaki altyapının yeterliğine ve eğitimle ilgili sistemlerin en iyi şekilde uygulanmasına bağlıdır ${ }^{10}$.

Eğitim, öğrencilerin davranışlarında, düşüncelerinde, alışkanlıklarında ve yeteneklerinde; değişimlerin ve gelişimlerin oluşturulması süreci olup, belli bir amaca yönelik olarak daha önceden yapılandırılmış ve planlanmış olan faaliyetlerdir. Sürekli gelişen ve değişen bir yapı gösteren eğitim faaliyetlerinin, modern eğitim anlayışı çerçevesinde gelişmesi ve oluşan ihtiyaçlara göre yenilenmesi gerekmektedir ${ }^{11}$. Diğer bir iafadeyle, eğitim faaliyetleri, öğrencilerin kişilik oluşumlarını, çevrelerine karşı sosyalleşmelerini, ortaya çıkan problemlere çözümler üretebilmelerini ve problemleri çözebilme yeteneklerinin artırılmasını amaçlamalıdır ${ }^{12}$.

8 S. Güney, İnsan Kaynakları Yönetimi, 2. bs., İstanbul, Nobel Akademik Yayınları, 2015, s. 119.

9 A. R. Terzi, "Sınıf Yönetimi Açısından Etkili Öğretmen Davranışları”, Milli Eğitim Dergisi, say1 155, 2002, s. 162.

10 G. Ekici, "Sınıf Yönetimi Dersinin Öğretmen Adaylarının Öğretmen Öz-Yeterlik Algı Düzeyine Etkisi”, Hacettepe Üniversitesi Ĕ̈itim Fakültesi Dergisi, sayı 35, 2008, s. 99.

11 A. Aydın, Sinıf Yönetimi, 20. bs., Ankara, Pegem Akademi Yayınları, 2019, s. 3.

12 M. Çakmak, "Öğretmen Adaylarının Sınıf Yönetimi Stratejilerine Yönelik Görüşleri”, Hacettepe Üniversitesi Ĕ̈itim Fakültesi Dergisi, say1 35, 2008, s. 53. 
Sınıf ortamında etkili öğrenme ve öğretme süreçlerinin gerçekleşebilmesi için öğretmenlerin programlı ve planlı olması, öğretimle ilgili teknik, araç gereçleri, materyal ve yöntemlerin en verimli şekilde kullanması gerekmekte ve etkili bir sınıf yönetimi için öğretmenlerin bilgi donanımlarının iyi olması, iyi bir rehberlik yapmaları ve öğrencilerin motivasyonunun sağlanması açısından büyük önem arz etmektedir. Motivasyonu arttırılan öğrencilerden meydana gelen sınıfta, öğrenme öğretme faaliyetlerini kolaylaşmakta, sınıflarda istenmeyen davranışlar azalmakta ve sınıf yönetimi daha rahat sağlanabilmektedir. Öğretmenlerin etkili bir sınıf yönetimi sağlayabilmeleri için sınıf düzenini sağlamaları, yeni gelişen öğretim yöntemlerini uygulamaları, zamanı iyi bir şekilde yönetmeleri ve öğrencilerle iyi iletişim içinde olmaları gerekmektedir ${ }^{13}$.

Etkili sınıf yönetim faaliyetleri; teknolojiye dayalı sistemler, araç gereçler, materyaller ve yöntemlerle öğrenim başarılı olmakta ve öğrencilerin motivasyonun artmasına neden olmakta, yüksek motivasyona sahip öğrenciler ve başarıyla öğrenim faaliyetlerini yürüten öğretmenler için eğitim faaliyetleri eğlenceli bir etkinliğe dönüşe bilmekte, sınıf içindeki düzenin sağlanması daha da kolay hale gelmektedir ${ }^{14}$. Öğretmenlerin etkili sınıf yöntimi aynı zamanda öğrencilerin okulda kazanmış olduğu bilgi ve beceriler onların hayata daha uyum sağlamalarına ve aileleri ile olan ilişkilerinin daha iyi bir seviyeye gelmesine neden olmaktadir ${ }^{15}$.

Stratejik bir öneme sahip olan öğretmenlik mesleği, hoşgörü, sabır, bilgi, beceri, iyi iletişim ve deneyimli olmayı gerektirmektedir ${ }^{16}$. Öğretmenler karşılaşmış oldukları sorunları, çeşitli öğretim tekniklerini ve yöntemlerini öğrenerek, okuldaki diğer öğretmenler ile iletişim sağlayarak, onlara danışarak veya uzman yardımı ile çözüme kavuşturabilirler ${ }^{17}$. Sınıf yönetiminde öğrenci davranışlarının da en iyi şekilde yönetilmesi gerekmektedir. Bu kapsamda, öğretmenlerin davra-

13 H. H. Özkan, “Öğrenme Öğretme Modelleri Açısından Modüler Öğretim”, Atatürk Üniversitesi Sosyal Bilimler Enstitüsü Dergisi, cilt 6, sayı 2, 2005, s. 118.

14 H. V. Bayraktar, "Sinıf Yönetiminde Öğrenci Motivasyonu ve Motivasyonu Etkileyen Etmenler", International Periodical For The Languages, Literature and History of Turkish or Turkic, cilt 10, say1 3, 2015, s. 1079.

15 E. Akgün - M. Yarar - Ç. Dinçer, "Okul Öncesi Öğretmenlerin Sınıf İçi Etkinliklerde Kullandıkları Sınıf Yönetimi Stratejilerinin İncelenmesi”, Pegem Eğitim ve Öğretim Dergisi, cilt 1, say1 3, 2011, s. 3.

16 B. Sucuoğlu, “Okul Öncesi Sınıflarda Kaynaştırma ve Sınıf Yönetimi”, Çoluk Çocuk Dergisi, say1 40, 2008, s. 41.

17 B. Yaman, "Pedagojik Formasyon Eğitimi Almamış Öğretmenlerin Sınıf Yönetimi Algıları / Aksaray ili Örneği”, Elektronik Sosyal Bilimler Dergisi, cilt 9, sayı 31, 2010, s. 54. 
nışlarının öğrencilere örnek olması, öğrencilerin birbirleri arasında iyi iletişim kurmalar1 ${ }^{18}$, ailelerin çocuklarına karşı iyi davranmaları sonucunda; öğrencilerin kişilikleri de olumlu yönde etkilenecektir ${ }^{19}$. Etkili bir iletişimin olabilmesi için okuldaki yöneticiler öğretmenler ve öğrenciler arasında empatiye dayalı bir anlayış, saygı ve sevgi çerçevesinde hizmetler yürütülmelidir ${ }^{20}$. Ayrıca etkili iletişimin olumlu ve olumsuz durumlar dahil her aşamada sürdürülmesi gerekmektedir ${ }^{21}$.

Sınıf yönetimi, en önemli ihtiyaçların göz önünde bulundurulması, öğrenciyi çok yönlü geliştirerek eğiten programlar düzenlenmesi, öğrenmenin merkez alındığı oyunların oynanması gibi uygulamalarla alakalı davranış, bilgi ve becerilerin tümünü kapsamaktadır. Öğrencilerin belirlenmiş olan bir düzen içinde, olumlu bir iletişim ortamı çerçevesinde, tutarlı öğretmen davranışı sergilenen ve sınıfın öğretmenlerin kontrolü üstünde olduğu sınıf ortamlarında çocukların da öğrenmeleri kolaylaşmaktadır. Öğretmenlerin sınıf yönetimindeki becerileri, öğrencilerin başarıları üzerinde etkili olmakla birlikte sınıf yönetimi hususunda öğretmenlerin, donanımlı ve bilgili olmaları önem arz etmektedir ${ }^{22}$.

Öğretmenlerin sınıf yönetimi ve sınıf içi davranışları ile ilgili disiplin modellerini dikkate alınmaları, sınıf etkinliklerinde literatüde yer alan düşüncelerden yararlanabilmeri açısından önemli faydalar sağlayabilive bu modeller aşağıdaki şekilde sıralanabilir ;

1. Canter ve Canter'in (1985) “Güvengen Disiplin Modeli”nde; öğretmenlerin sınıf içinde daha aktif olmasını, sorumluluk üstlenmelerini ve öğrencilere karş1 sakin olmaları önerilmektedir. Kriz ve güvene dayalı olmayan durumlarda bireylerin saldırgan davranışlar sergileyeceklerdir. Bu nedenle öğretmenlerin sınıfta çıkacak sorunların engellenebilmesi için önlem almaları ve disipline karşı olan öğrencilere göz yumulmaması gerekir ${ }^{23}$.

18 U. Akın - R. Koçak, "Öğretmenlerin Sınıf Yönetimi Becerileri ile İş Doyumları Arasındaki İlişki”, Educational Administration: Theory and Practice, sayı 51, 2007, s. 355.

19 M. Zontul - C. A. Mert, "Sınıf İçi Davranış Problemlerinin Çözümünde Davranış Yönetim Sisteminin Etkisi”, Eğitim ve Öğretim Araştırmaları Dergisi, cilt 4, sayı 4, 2015 , s. 96.

20 I. Gürşimşek, "Etkin Sınıf Yönetimi İçin Etkili İletişim Becerileri”, Eğitim ve Bilim, cilt 23, say1 112, 1999, s. 42.

21 Z. Çetinkaya, "Türkçe Öğretmen Adaylarının İletişim Becerilerine İlişkin Görüşlerinin Belirlenmesi”, Kastamonu Eğitim Dergisi, cilt 19, sayı 2, 2011, s. 567.

22 G. U. Balat, "Sınıf Yönetimi Kavramı ve Sınıf Yönetimi Modelleri”, Okul Öncesi Eğitimde Sinıf Yönetimi, (içinde), ed. G. U. Balat, Ankara, Eğiten Kitap, 2013, s. 8.

23 K. Çelik, "Disiplin Oluşturma ve Kuram Geliştirme”, Etkili Sınıf Yönetimi, (içinde), ed. H. Kiran, Ankara, Anı Yayıncılık, 2007, s. 250. 
2. Skinner Davranış Değiştirme Modeline göre; öğrenme çevrenin etkisi ile oluşur, davranışlar daha sonradan öğrenilir, pekiştirilen davranışlar gelişir, ödüllendirilmiş ve pekiştirilmemiş davranışlar ise zamanla unutulur ${ }^{24}$.

3. "Glasser'in Gerçeklik Terapisi ya da Kontrol Modeli”; 1960'larda William Glasser tarafından geliştirilmiş olup diğer insanlara zarar vermeksizin, ihtiyaçlarıyla uyum içinde seçimlerini kendilerinin yapmasına yardım etmek, gerçeklik terapisinin temelinde yer almaktadır. Gerçeklik terapisi ya da kontrol modelinden, okullarda ve madde bağımlılığ kliniklerinde yaygın olarak yararlanıldığı belitrilmektedir ${ }^{25}$.

4. "Gordon'un Öğretmen Etkinliği Modeli”; Gordon tarafından 1974 y1lında geliştirilmiş olup, öğretmenlerin sorunları çözebilmek amacıyla sorunların sebeplerini ve sonuçlarını incelemesi gerektiğini ileri sürmüştür. Ortaya çıkan sorunun sebebi öğrenci kaynaklı olduğunda, öğretmenlerin öğrencileri ile görüşmesi ve onlara rehberlik yapmasi gerekmektedir. Bunun yanı sıra sorunun kaynağı öğretmen olduğunda ise öğretmenlerle öğrencilerin ortaya çıkan sorunları işbirliği içinde çözmeleri önerilmektedir ${ }^{26}$.

5. "Dreikurs'un Mantıksal Sonuçlar Modeli"; Dreikurs (1968) tarafından geliştirilmiş olup, öğrencilerin istenilen şekilde davranmasını zorlamaktan ziyade, öğrencilere seçenekler sunulması ilkesi esas alınmaktadır. Bireylerin yanlış davranışları; güç ihtiyacı, yetersizlik duygusu, ilgi ihtiyacı ve öç alma ihtiyacı sebebiyle sergilenebilmekte ve davranışların sebebinin belirlenmesi büyük önem taşımaktadır ${ }^{27}$.

Etkili bir sınıf yönetimi için örgüt ikliminin; öğretmenler öğrenciler, aileler ve çalışanlar açısından destek görmesi ${ }^{28}$ için okullarda memnuniyetin sağlanabilmesi için tüm tarafların beklentilerinin karşılanabilmesini gerektirmektedir ${ }^{29}$. Örgütsel

24 Ö. Çelikkaleli - Y. İnandı, "İlköğretim Öğretmenlerinde Disiplin Anlayışı ve Kişilerarası İlişkiye Yönelik Yetkinlik İnancının İncelenmesi”, Pegem Ĕ̆itim ve Öğretim Dergisi, cilt 2, say1 2, 2012, s. 16.

25 O. Akpınar - F. S. Öz, “Gerçeklik Terapisi: Özellikler, Temel Kavramlar, Tedavi, Uygulama ve Değerlendirme”, Electronic Journal of Social Sciences, cilt 12, say1 43, 2013, s. 1.

26 T. Gordon, Etkili Öğretmenlik Ĕgitimi, çev. E. Aksoy, İstanbul, Sistem Matbaacılık, 1974, s. 25.

27 C. H. Edwards - V. J. Watts, Classroom Discipline \& Management: an Australasian Perspective, Australia, Milton, Wiley, 2004, s. 36.

28 H. Başar, Sınıf Yönetimi, İstanbul, Milli Eğitim Bakanlığı Yayınları, 1999, s. 13.

29 M. Gürsel, Sınıf Yönetimi, Yenilenmiş 3. bs., Konya, Eğitim Akademi Yayınları, 2011, s. 6. 
iklimi ilgilendiren fiziksel yapı; okul binasının 1sınması, kullanılan renkler, sınıfların aydınlığı, gürültünün önlenmesi, Estetik, sınıfların oturma düzeni, araç gereçlerin yeni gelişmelere uygun olması gibi konuları kapsamaktadır ${ }^{30}$. Örgüt ikliminde bir diğer önemli faktör öğretmenlerdir. Öğretmenlerin yetenekleri, s1nıf yönetim tecrübesi, iletişim becerileri, araç gereçleri kullanmadaki başarısı, yeni bilgilere açık olması ve başarıya odaklı vizyona sahip olması gerekmektedir ${ }^{31}$. Öğretmenlerin ve ailenin çocukların tüm sorunları ile ilgilenmesi, eksiklerini gidermesi, yeteneklerine göre destek sağlaması, anlayışlı olması ve sorunların çözümünde yapıcı olmaları gerekmektedir ${ }^{32}$. Okul ikliminde öğretmenlerin çabarına dolaylı olarak katkısı olan diğer bir unsur ailenin çocuğunun eğitim faaliyetlerine desteğidir ${ }^{33}$, çocuklar ilk eğitimlerini aileden almakta, okullarında kariyerlerini geliştirmekte, kişilikleri oluşmakta fiziksel, sosyal ve psikolojik yönden gelişmelerini sağlamaktadırlar ${ }^{34}$.

\section{Yöntem}

Bu çalı̧̧mada, nicel yöntemlerden, ilişkisel tarama modeli esas alınmış olup bu tür modelde iki veya ikiden fazla değişkeni narasındaki ilişki araştırılmaktadır ${ }^{35}$. Katılımcıların seçimi ise belirlenmiş olan evrende ön seçim olmadan, her bireyin eşit olarak seçilebilmesini sağlamak için basit tesadüfi örnekleme yöntemiyle yapılmıştır.

30 Başar, a.g.e., s. 14.

31 M. Okutan, Sinıf Yönetiminde Örnek Olaylar, Ankara, Öğreti-Pegem Akademik Yayıncılık, 2004, s. 5.

32 Ş. Kapusuzoğlu, "Okul Öncesi Sınıf Yönetimi Uygulamalarıyla Aile Tutumunun Çocuğun Gelişim Özelliklerine Etkisinin Değerlendirilmesi”, Abant İzzet Baysal Üniversitesi Sosyal Bilimler Enstitüsü Dergisi, cilt 2, say1 12, 2006, s. 53.

33 F. T. Şahin - F. N. C. Kalburan, "Aile Eğitim Programları ve Etkililiği: Dünyada Neler Uygulanıyor?”, Pamukkale Üniversitesi Eğitim Fakültesi Dergisi, cilt 1, sayı 25, 2009, s. 2.

34 U. Özgün - A. Kandır, "Okul Öncesi Dönemde Erken Akademik Beceriler”, Kuramsal Eğitimbilim Dergisi, cilt 3, say1 2, 2010, s. 118.

35 Ş. Büyüköztürk - E. K. Çakmak - Ö. E. Akgün - Ş. Karadeniz - F. Demirel, Bilimsel Araştırma Yöntemleri, 25. bs., Ankara, Pegem Akademi Yayınları, 2017, s. 79. 


\subsection{Araştırmanın Modeli ve Hipotezleri}

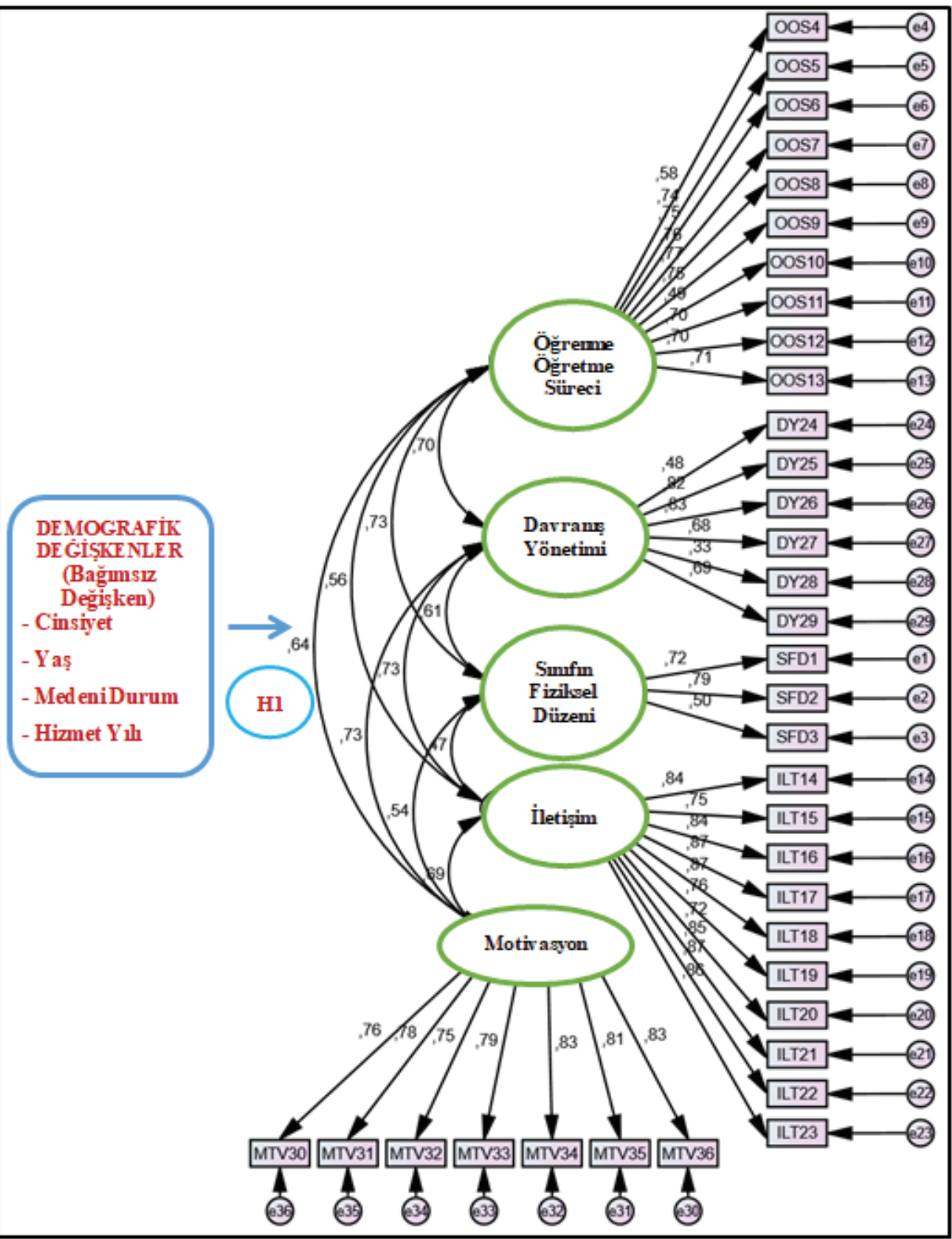

Şekil 1. Demografik Değişkenler ve Okul Öncesi Öğretmenlerinin Sınıf Yönetimi Becerileri ilişkisine Yönelik İstatistiksel Model 
Araştırma için kurulan istatistiksel şekil 1'deki ilişkisel model incelendiğinde: ögrrenme-öğretme süreci 10 madde, davranış yönetimi 6 madde, "sınıfin fiziksel durum" boyutu ve 3 madde, iletişim 10 madde, motivasyon 6 maddedir ve her bir boyutun maddelerine ait hata terimleri e1, e2, e3 şeklinde modele eklenmiştir. Maddelerin birbirini açıklama yüzdeleri ve boyutlar arasındaki korelasyon değerleri modelde görülmektedir.

\subsection{Araştırmanın Hipotezleri}

H1: Sınıf yönetimi becerileri, öğretmenlerin demografik özeliklerine göre farkl111k gösterir.

H1a1: Sınıfın fiziksel düzeni, öğretmenlerin cinsiyetlerine göre farklılık gösterir.

H1a2: Öğrenme-öğretme süreçleri, öğretmenlerin cinsiyetlerine göre farklil1k gösterir.

H1a3:İletişimin etkinliği, öğretmenlerin cinsiyetlerine göre farklılık gösterir.

H1a4: Davranış yönetimi becerisi, öğretmenlerin cinsiyetlerine göre farkl111k gösterir.

H1a5: Motivasyon sağlama becerisi, öğretmenlerin cinsiyetlerine göre farkl111k gösterir.

H1b1: Sınıfın fiziksel düzeni, öğretmenlerin medeni durumlarına göre farklılık gösterir.

H1b2: Öğrenme-öğretme süreçleri, öğretmenlerin medeni durumlarına göre farklılık gösterir.

H1b3: İletişimin etkinliği, öğretmenlerin medeni durumlarına göre farkl1lık gösterir.

H1b4: Davranış yönetimi becerisi, öğretmenlerin medeni durumlarına göre farkl111k gösterir.

H1c5: Motivasyon sağlama becerisi, öğretmenlerin medeni durumlarına göre farklılık gösterir.

H1c1: Sınıfın fiziksel düzeni, öğretmenlerin öğrenim durumlarına göre farklılık gösterir.

H1c2: Öğrenme-öğretme süreçleri, öğretmenlerin öğrenim durumlarına göre farkl1lık gösterir. 
H1c3: İletişimin etkinliği, öğretmenlerin öğrenim durumlarına göre farkl1l1k gösterir.

H1c4: Davranış yönetimi becerisi, öğretmenlerin öğrenim durumlarına göre farklılık gösterir.

H1c5: Motivasyon sağlama becerisi, öğretmenlerin öğrenim durumlarına göre farkl111k gösterir.

H1d1: Sınıfın fiziksel düzeni, öğretmenlerin hizmet süresine göre farklılık gösterir.

H1d2: Öğrenme-öğretme süreçleri, öğretmenlerin hizmet süresine göre farkl111k gösterir.

H1d3: İletişimin etkinliği, öğretmenlerin hizmet süresine göre farklılık gösterir.

H1d4: Davranış yönetimi becerisi, öğretmenlerin hizmet süresine göre farkl1lık gösterir.

H1d5: Motivasyon sağlama becerisi, öğretmenlerin hizmet süresine göre farkl111k gösterir.

\section{3. Çalışma Grubu Evren ve Örneklem}

Araştırmanın evreni İstanbul ili Avcılar ilçesinde resmi ilkokullarda okul öncesi eğitim kurumlarında çalışmakta olan 682 adet sınıf öğretmenini kapsamaktadır. Yazıcıoğlu ve Erdoğan (2004)'a ait “Örneklem Büyüklükleri” tablosu dikkate alındığında 682 kişilik evren için \%5 örnekleme hatasıyla sahip 254 kişiye anket uygulanmasının yeterli olacağı tespit edilmiştir. Dolayısıyla geçersiz olacak veya geriye dönmeyecekler anketler olabileceği düşünülerek, toplam 550 kişiye basit tesadüfi örnekleme yöntemiyle katılımcılar belirlenerek 25.04.2021- 28.06.2020 tarihleri arasında anket uygulaması yapılmış ve sonuçta geriye dönen 509 geçerli anket verilerinden yararlanılarak analizler tamamlanmıştır ${ }^{36}$.

\subsection{Veri Toplama Araçları}

Bu çalışmanın anketinin ilk bölümünde demografik bilgileri almaya yönelik maddeler ve okul öncesi öğretmenlerinin sınıf yönetimi becerileri üzerine etkilerini belirlemeye yönelik 5 boyut ve 36 maddelik, Ergen'in (2013) geliştirdiği “'S1nıf Yönetimi Ölçeği Öğretmen Formu”ndan yararlanılmıştır. Ölçeğe ait cronba-

36 Y. Yazıcı̆ğlu - S. Erdoğan, SPSS Uygulamalı Bilimsel Araştırma Yöntemleri, Ankara, Detay Yayınc1l1k, 2004, s. 50. 
chalpha katsayının ise 0,82 olarak hesaplandığı belirtilmiştir. Söz konusu ölçek; sınıfın fiziksel düzeni (3 madde), öğrenme-öğretme süreci (10 madde), iletişim (10 madde), davranış yönetimi (6 madde) ve motivasyon (7 madde) olmak üzere toplam 5 boyut ve 36 maddeden oluşmaktadır. Katılımcılardan ölçek sorularını; 1- hiçbir zaman, 2-nadiren, 3-ara sıra, 4-sık sık ve 5- her zaman şeklince cevaplandırmaları istenen 5'li likert tipi sorulardan oluşmaktadır ${ }^{37}$.

\subsection{Verilerin Analizi}

$\mathrm{Bu}$ araştırmada, ankete katılan okul öncesi öğretmenlerden elde edilmiş olan veriler IBM SPSS 22 programı kullanılarak analiz edilmiştir. Demografik değişkenlere göre farklılıkların incelendiği analizlerde bağımsız örneklem t-testi ve one way anova analizinden yararlanılmıştır ve analizler sonucunda farklılık olup olmadığına SPSS paket programında verilen p değerine bakarak karar verilmiştir. Örnek olarak uygulanan test sonucunda verilen $\mathrm{p}$ değeri alfa değerinden küçük olursa ilgili değişkenin demografik değişkene göre farklılık gösterdiği şeklinde yorumlanmıştır. Yapılan testlerde alpha katsayısı 0,05 olarak alınmıştır ${ }^{38}$.

\section{Bulgular}

\subsection{Sınıf Yönetimi Becerileri Ölçeği İçin Güvenilirlik Analizi}

Çalışmada kullanılması uygun görülen sınıf yönetimi ölçeğine ait boyutlar için sınıfın fiziksel düzeni (3 madde), öğrenme-öğretme süreci (10 madde), iletişim (10 madde), davranış yönetimi (6 madde) ve motivasyon (7 madde) olmak üzere 5 boyut ve 36 madde, istatistiksel analiz yöntemlerinden güvenilirlik analizi yapılmış ve elde edilen bulgular aşağıda Tablo 1'de sunulmuştur.

37 Y. Ergen, "Sınıf Öğretmenlerinin Sınıf Yönetim Becerileri, Akademik İyimserlikleri ve Mesleki Bağl11ıkları Arasındaki İlişki”, (Yayımlanmamış Doktora Tezi), Ondokuz Mayıs Üniversitesi Eğitim Bilimleri Enstitüsü, Samsun, 2013, s. 208.

38 Ş. Büyüköztürk, Sosyal Bilimler için Veri Analizi El Kitabı, Ankara, Pegem A Yayıncılık, 2007, s. 78 . 
Tablo 1. Sınıf Yönetimi Becerileri Ölçeğinin Güvenirlik Analizi Değerleri

\begin{tabular}{|c|c|c|c|}
\hline Boyut & Madde & $\mathbf{P}$ değeri & $\begin{array}{c}a \\
(0.950)\end{array}$ \\
\hline \multirow{3}{*}{ 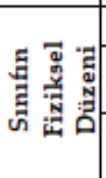 } & 1. Sunuf içi fiziksel koșullann (1sı, ıșık, gürültü) kontrol ederim. & \$** & \multirow{3}{*}{0,637} \\
\hline & $\begin{array}{l}\text { 2. Suruf içinde doğabilecek kaza ve tehlikelere karșı gerekli güvenlik } \\
\text { önlemlerinu alunm. }\end{array}$ & 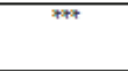 & \\
\hline & $\begin{array}{l}\text { 3. Surufm fiziksel düzenlenumesinde öğrencilerin görüșlerinden } \\
\text { yararlanumm. }\end{array}$ & \$77 & \\
\hline \multirow{10}{*}{ 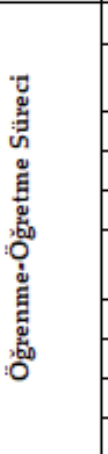 } & 4. Ögrencilere derse ilișkin beklentilerimi açılarmm. & **7 & \multirow{10}{*}{0,887} \\
\hline & $\begin{array}{l}\text { 5. Öğrencilerin gelişimsel özelliklerini göz önünde bulundurarak } \\
\text { ögrenune-öğretme sürecini düzenlerim. }\end{array}$ & w7* & \\
\hline & 6. Öğrenune-ŏğretme sürecinde bireysel farklhllklan dikkate alumm. & **7 & \\
\hline & 7. Öğrencilerin ögrenune-ögretme sürecinde aktif katılunuru sağlayacak & *\$7 & \\
\hline & 8. Dersin bașmda öğrencileri derse hazurlarmm. & **7 & \\
\hline & $\begin{array}{l}\text { 9. Dersin luzun ve akıșuu ögrencilerin öğrenme düzeyine göre } \\
\text { ayarlarmm. }\end{array}$ & \$कF & \\
\hline & 10. Olçme ve değerlendirmenin nasıl yaplacağı konusunda oğrencileri & \$** & \\
\hline & 11. Oğrencilerin ders içi ve ders dıṣı zamanlanun etkili kullanunalan için & \$*F & \\
\hline & 12. Ders zamaruu etkinliklere göre ayarlarm. & \$7* & \\
\hline & 13. Oğrenune -ögretme sürecinde zamaru etkin kullarurmm. & *⿻肀 & \\
\hline \multirow{10}{*}{$\begin{array}{l}\text { 礐 } \\
\text { 总 }\end{array}$} & $\begin{array}{l}\text { 14. Oğrencilerle iletişim kurarken nezaket kurallarma uygun } \\
\text { davranum. }\end{array}$ & WW & \multirow{10}{*}{0,951} \\
\hline & $\begin{array}{l}\text { 15. Suruf içinde çok yönlü (öğretmen-öğrenci, öğrenci-öğrenci) iletişim } \\
\text { sağlarm. }\end{array}$ & P*T & \\
\hline & 16. Suruf içi iletișimde acık, sade ve anlașlur bir dil kullarurum. & \$\#+ & \\
\hline & 17. Suruf içi iletişimde beden dili, jest ve mimikleri kullanurum. & \$*7 & \\
\hline & 18. Oğrencilerle göz teması kuranm. & \$* & \\
\hline & 19. Sesimi etkili bir şekilde kullarurum. & \$N" & \\
\hline & 20. Demokratik bir suuf atmosferi oluștururum. & \$*4 & \\
\hline & 21. Oğrencilere güler yüzlü, hoșgörülü ve içten davranurmm. & \$** & \\
\hline & 22. Surftaki tüm oğrencilere eşit ve adil davrarurm. & wat & \\
\hline & 23. Oğrencilerin fikirlerine ve ürettiklerine değer veririm. & \$*\$ & \\
\hline \multirow{6}{*}{ 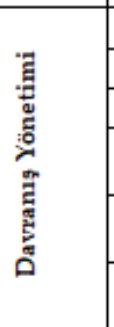 } & 24. Suruf kurallarnu, ögrencilerle birlikte belirlerim. & F⿻十 & \multirow{6}{*}{0,762} \\
\hline & 25. Kurallarnn kısa, açık ve anlașlır olmasma dikkat ederim. & 7*7 & \\
\hline & 26. Sunf kurallanum uygulanmasuru takip ederim. & 7*7 & \\
\hline & $\begin{array}{l}\text { 27. Istenmeyen (olumsuz) davranușlara dersin akıșuu bozmadan } \\
\text { müdahale ederim. }\end{array}$ & \$A* & \\
\hline & $\begin{array}{l}\text { 28. Oğrencilerin yaptıklan isterumeyen (olumsuz) davrarușlar süreklilik } \\
\text { göstermiyorsa gömpzzden gelirim. }\end{array}$ & F+7 & \\
\hline & $\begin{array}{l}\text { 29. Istenmeyen (olumsuz) davrarușlar karșısmda kararlı ve tutarl } \\
\text { davrarurm. }\end{array}$ & \$*\$ & \\
\hline \multirow{7}{*}{ 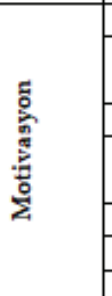 } & 30. Dersin bașmnda öğrencileri güdülerim. & \$F+ & \multirow{7}{*}{0,920} \\
\hline & $\begin{array}{l}\text { 31. Sunftaki tüm oğrencilerin derse ve etkinliklere katılmunu teşvik } \\
\text { ederim. }\end{array}$ & 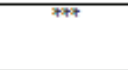 & \\
\hline & 32. Oğrencilerin ilgi ve derse katılmunu ders boyunca sürdürürüm. & $\$+4$ & \\
\hline & $\begin{array}{l}\text { 33. Oğrencileri dikkati dağıldığmda dikkatlerini toparlayıc etkinlikler } \\
\text { yaparm. }\end{array}$ & F⿻肀 & \\
\hline & 34. Oğrencilerin olumlu davrarușlanuru pekiștiririmn. & P\$+ & \\
\hline & 35. Sunuftaki tüm ögrencilerle ilgilenirim. & F** & \\
\hline & 36. Oğrencilere bașan duygusunu yașatmaya çalıșumm. & \$कF & \\
\hline
\end{tabular}


Sınıf yönetimi becerileri ölçeğinin geneli için güvenilirlik katsayısının 0,950 olduğu gözlenmiştir. Bu değere bakarak ölçeğin yüksek güvenilirlikte olduğu söylenebilir. Ayrıca ölçeğin alt boyutlarından sınıfın fiziksel düzeni (Cronbach Alfa $=0,637$ ), öğrenme-öğretme süreci (Cronbach Alfa $=0,887$ ), iletişim (Cronbach Alfa $=0,951$ ), davranış yönetimi becerisi (Cronbach Alfa $=0,762$ ) ve motivasyon sağlama becerisi (Cronbach Alfa $=0,920$ ) için hesaplanan Cronbach Alfa değerlerine bakarak alt boyutlarında oldukça güvenilir olduğu söylenebilir. Sonuç olarak Sınıf Yönetimi Becerileri Ölçeği'ni oluşturan 36 maddenin oluşturduğu 5 boyutlu yapının güvenilirlik analizi ile test edilmesiyle güvenilir ve geçerli bir ölçek olduğu tespit edilmiştir.

\subsection{Frekans Analizi}

Araştırma sonucunda elde edilen bulgular özet tablolar halinde sunulmuştur. Araştırma için seçilen örneklemin cinsiyet, medeni durum, öğrenim durumu ve öğretmenlik mesleğinde hizmet yılı dağılımlarını incelemek amacıyla frekans analizinden yararlanılmıştır.

Tablo 2. Demografik Değişkenlerin Frekans Tablosu

\begin{tabular}{|l|l|l|l|}
\hline \multicolumn{2}{|c|}{} & Frekans & Yüzde \\
\hline \multirow{3}{*}{ Cinsiyet } & Kadın & 494 & $97,1 \%$ \\
\cline { 2 - 4 } & Erkek & 15 & $2,9 \%$ \\
\hline \multirow{4}{*}{ Medeni Durum } & Bekâr & 202 & $39,7 \%$ \\
\cline { 2 - 4 } & Evli & 307 & $60,3 \%$ \\
\hline \multirow{4}{*}{$\begin{array}{l}\text { Öğretmenim Durumu } \\
\text { Mesleğinde Hizmet }\end{array}$} & Ön Lisans & 67 & $13,2 \%$ \\
\cline { 2 - 4 } & Fakülte & 409 & $80,4 \%$ \\
\cline { 2 - 4 } & Yüksel Lisans & 33 & $6,5 \%$ \\
\hline & $0-4$ Y11 & 137 & $26,9 \%$ \\
\cline { 2 - 4 } & 5-9 Y11 & 118 & $23,2 \%$ \\
\cline { 2 - 4 } & $10-14$ Y11 & 130 & $25,5 \%$ \\
\cline { 2 - 4 } & $15-19$ Y11 & 63 & $12,4 \%$ \\
\cline { 2 - 4 } & 20 Y11+ & 61 & $12,0 \%$ \\
\hline
\end{tabular}

Tablo 2'de örnekleme ait dağılımlar incelendiğinde 509 gönüllü öğretmenin araştırmaya katıldığı görülmektedir ve bu katılımcılardan 494 kişinin kadın ve 15 kişinin erkek olduğu görülmektedir. Medeni durum dağılımına bakıldığında 202 kişinin bekâr ve 307 kişinin evli olduğu gözlenmiştir. Katılımc1 öğretmenlerin 
eğitim durumları incelendiğinde 67 kişinin ön lisans (\%16,9), 409 kişinin fakülte (lisans) $(\% 80,4)$ ve 33 kişinin ise lisansüstü $(\% 6,5)$ düzeyinde eğitim aldığı gözlenmiştir. Son olarak katılımc1 öğretmenlerin hizmet süreleri incelendiğinde 197 kişinin 0-4 yıl (\%26,9), 118 kişinin 5-9 saat $(\% 23,2)$ arasında, 130 kişinin 10-14 yıl $(\% 25,5)$ arasında, 63 kişinin $15-19$ yıl $(\% 12,4)$ arasında, 61 kişinin 20 yıl ve üzerinde $(\% 12,0)$ olduğu görülmektedir.

\subsection{Demografik Değiş̧kenler ile Sınıf Yönetimi Becerileri Arasındaki İlişki İçin t-Testi ve One Way Anaova Testi}

Yapılan uygulama çalışmasında elde edilen veriler IBM SPSS 22 programı kullanılarak analiz edilmiştir. Demografik değişkenlere göre farklılıkların incelendiği analizlerde bağımsız örneklem t-testi ve One Way Anaova testinden yararlanılmıştır. Yapılan testlerin sonucunda farklılık olup olmadığına SPSS paket programında verilen $\mathrm{p}$ değerine bakarak karar verilmiştir. Örnek olarak uygulanan test sonucunda verilen $p$ değeri alfa değerinden küçük olursa ilgili değişkenin demografik değişkene göre farklılık gösterdiği şeklinde yorumlanmıştır. Yapılan testlerde alpha katsayısı 0,05 olarak alınmıştır. Dolayısıyla sınıf yönetimi becerilerinin demografik değişkenlerden cinsiyet, medeni durum, öğrenim durumu, hizmet süresine göre değişimleri incelenmiştir. Farklılık mevcudiyeti ve bu farklılığa sebep olan etkenler için t-testi ve One Way Anaova testleri ygulandıktan sonra elde edilen sonuçlar özet tablolar haline sunulmuştur.

\subsection{Sınıf Yönetimi Becerilerinin Cinsiyete Göre Değişimi}

Tablo 3. Cinsiyet ile Sınıf Yönetimi Becerileri Arasındaki İlişki İçin T-Testi Sonuçları

\begin{tabular}{|c|c|c|c|c|c|c|c|}
\hline \multirow{11}{*}{$\begin{array}{l}0 \\
0 \\
0\end{array}$} & Düzeyler & Cinsiyet & $\mathbf{N}$ & Ort. & $\begin{array}{l}\text { t } \\
\text { Değeri }\end{array}$ & $\begin{array}{l}\text { p } \\
\text { Değeri }\end{array}$ & Hipotez \\
\hline & \multirow{2}{*}{$\begin{array}{l}\text { Sinıfin Fiziksel } \\
\text { Düzeni }\end{array}$} & Kadın & 494 & 4,4561 & \multirow[t]{2}{*}{1,492} & \multirow[t]{2}{*}{,036 } & \multirow{2}{*}{$\begin{array}{l}\text { H1al } \\
\text { Kabul }\end{array}$} \\
\hline & & Erkek & 15 & 4,2444 & & & \\
\hline & \multirow{2}{*}{$\begin{array}{l}\text { Öğrenme- } \\
\text { Öğretme Süreci }\end{array}$} & Kadın & 494 & 4,5698 & \multirow{2}{*}{1,577} & \multirow{2}{*}{,116 } & \multirow{2}{*}{ H1a2Red } \\
\hline & & Erkek & 15 & 4,3800 & & & \\
\hline & \multirow{2}{*}{ İletişim } & Kadın & 494 & 4,7935 & \multirow[t]{2}{*}{1,643} & \multirow[t]{2}{*}{,122 } & \multirow{2}{*}{ H1a3Red } \\
\hline & & Erkek & 15 & 4,5400 & & & \\
\hline & \multirow{2}{*}{$\begin{array}{l}\text { Davranış } \\
\text { Yönetimi }\end{array}$} & Kadın & 494 & 4,4480 & \multirow{2}{*}{,- 572} & \multirow{2}{*}{, 567} & \multirow{2}{*}{ H1a4Red } \\
\hline & & Erkek & 15 & 4,5222 & & & \\
\hline & \multirow{2}{*}{ Motivasyon } & Kadın & 494 & 4,6990 & \multirow{2}{*}{2,103} & \multirow{2}{*}{, 036} & H1a5 \\
\hline & & Erkek & 15 & 4,4476 & & & Kabul \\
\hline
\end{tabular}


H1a1: Sınıfın fiziksel düzeni, öğretmenlerin cinsiyetlerine göre farklılık gösterir.

H1a2: Öğrenme-öğretme süreçleri, öğretmenlerin cinsiyetlerine göre farkl11ık gösterir.

H1a3: İletişimin etkinliği, öğretmenlerin cinsiyetlerine göre farkl11ık gösterir.

H1a4: Davranış yönetimi becerisi, öğretmenlerin cinsiyetlerine göre farklılık gösterir.

H1a5: Motivasyon sağlama becerisi, öğretmenlerin cinsiyetlerine göre farkl11ık gösterir.

Çalışmada seçilen örneklemden elde edilen veriler yardımıyla sınıf yönetimi becerilerinin, cinsiyete bağlı gösterdiği değişiklikler t-testi yardımıyla incelenmiştir. Uygulanan t-testi sonucunda elde edilen sonuçlar incelendiğinde; öğretmenlerin sınıf yönetimi becerilerinden; öğrenme-öğretme süreci $(\mathrm{p}=0,116)$, iletişim $(p=0,122)$ ve davranış yönetimi becerisi $(p=0,567)$ için H1a2, H1a3 ve H1a4 hipotezlerinin reddedildiği ve cinsiyete göre farklılık göstermediği tespit edilmiştir $(\mathrm{p}<0,05)$.

Öğretmenlerin sınıf yönetimi becerilerinden; sınıfin fiziksel düzeni $(p=0,136)$ ve motivasyon sağlama becerisi $(\mathrm{p}=0,036)$ için H1a1 ve H1a5 hipotezinin kabul edildiği ve cinsiyete göre farkl11ık gösterdiği tespit edilmiştir $(\mathrm{p}<0,05)$.

\subsection{Sınıf Yönetimi Becerilerinin Medeni Duruma Göre Değişimi}

$\mathrm{Bu}$ bölümde sınıf yönetimi becerilerinin, demografik değişkenlere (cinsiyet, medeni durum, öğrenim durumu, hizmet süresi) göre değişimleri incelenmiştir. Farklılık mevcudiyeti ve bu farklılığa sebep olan etkenler için ilgili testler uygulandıktan sonra elde edilen sonuçlar özet tablolar halinde sunulmuştur. 
Tablo 4. Medeni Durum ile Sınıf Yönetimi Becerileri

Arasındaki İlişki için t-Testi Sonuçları

\begin{tabular}{|c|c|c|c|c|c|c|c|}
\hline \multirow{11}{*}{ 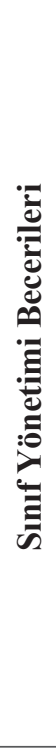 } & Düzeyler & $\begin{array}{l}\text { Medeni } \\
\text { Durum }\end{array}$ & $\mathbf{N}$ & Ort. & t Değeri & p Değeri & Hipotez \\
\hline & \multirow{2}{*}{$\begin{array}{l}\text { Sinıfın Fiziksel } \\
\text { Düzeni }\end{array}$} & Bekâr & 202 & 4,4307 & \multirow{2}{*}{,- 648} & \multirow{2}{*}{,517 } & \multirow{2}{*}{ H1b1Red } \\
\hline & & Evli & 307 & 4,4625 & & & \\
\hline & \multirow{2}{*}{$\begin{array}{l}\text { Öğrenme- } \\
\text { Öğretme } \\
\text { Süreci }\end{array}$} & Bekâr & 202 & 4,5752 & \multirow[b]{2}{*}{,437 } & \multirow[b]{2}{*}{,662 } & \multirow[b]{2}{*}{ H1b2Red } \\
\hline & & Evli & 307 & 4,5570 & & & \\
\hline & \multirow{2}{*}{ İletişim } & Bekâr & 202 & 4,8020 & \multirow{2}{*}{, 722} & \multirow{2}{*}{,470 } & \multirow{2}{*}{ H1b3Red } \\
\hline & & Evli & 307 & 4,7756 & & & \\
\hline & \multirow{2}{*}{$\begin{array}{l}\text { Davranış } \\
\text { Yönetimi }\end{array}$} & Bekâr & 202 & 4,4596 & \multirow{2}{*}{,346 } & \multirow{2}{*}{, 730} & \multirow{2}{*}{ H1b4Red } \\
\hline & & Evli & 307 & 4,4441 & & & \\
\hline & \multirow{2}{*}{ Motivasyon } & Bekâr & 202 & 4,6909 & \multirow{2}{*}{,- 024} & \multirow{2}{*}{,981 } & \multirow{2}{*}{ H1b5Red } \\
\hline & & Evli & 307 & 4,6919 & & & \\
\hline
\end{tabular}

H1b1: Sınıfın fiziksel düzeni, öğretmenlerin medeni durumlarına göre farkl111k gösterir.

H1b2: Öğrenme-öğretme süreçleri, öğretmenlerin medeni durumlarına göre farkl111k gösterir.

H1b3: İletişimin etkinliği, öğretmenlerin medeni durumlarına göre farklılık gösterir.

H1b4: Davranış yönetimi becerisi, öğretmenlerin medeni durumlarına göre farkl11ık gösterir.

H1c5: Motivasyon sağlama becerisi, öğretmenlerin medeni durumlarına göre farkl111k gösterir.

Çalışmada seçilen örneklemden elde edilen veriler yardımıyla sınıf yönetimi becerilerinin medeni duruma bağlı gösterdiği değişiklikler t-testi yardımıyla incelenmiştir. Uygulanan t-testi sonucunda elde edilen sonuçlar incelendiğinde öğretmenlerin sınıf yönetimi becerileri değişkenlerinden; sınıfın fiziksel düzeni ( $\mathrm{p}=0,136)$, öğrenme-öğretme süreci $(\mathrm{p}=0,116)$, iletişimin etkinliği $(\mathrm{p}=0,122)$, davranış yönetimi becerisi $(p=0,567)$ ve motivasyon sağlama becerisi $(p=0,036)$ için H1b1, H1b2, H1b3, H1b4 ve H1c5 hipotezlerinin reddedildiği ve medeni duruma göre farklılık göstermediği tespit edilmiştir $(\mathrm{p}<0,05)$. 


\subsection{Sınıf Yönetimi Becerilerinin Öğrenim Durumuna Göre Değişimi}

Tablo 5. Öğrenim Durumu ile Sınıf Yönetimi Becerileri

Arasındaki İlişki İçin One Way Anaova Testi Sonuçları

\begin{tabular}{|c|c|c|c|c|c|c|c|}
\hline \multirow{16}{*}{ 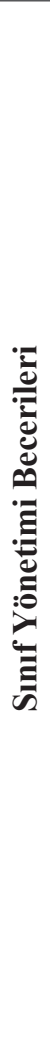 } & Düzeyler & $\begin{array}{l}\text { Öğrenim } \\
\text { Durumu }\end{array}$ & $\mathbf{N}$ & Ort. & f Değeri & p Değeri & Hipotez \\
\hline & & Ön Lisans & 67 & 4,4826 & \multirow{3}{*}{, 358} & \multirow{3}{*}{ 699 } & \multirow{3}{*}{$\begin{array}{l}\text { H1c- } \\
\text { 1Red }\end{array}$} \\
\hline & Fiziksel & Fakülte & 409 & 4,4401 & & & \\
\hline & Düzeni & Lisansüstü & 33 & 4,5051 & & & \\
\hline & Öğrenme- & Ön Lisans & 67 & 4,6119 & \multirow{3}{*}{1,249} & \multirow{3}{*}{, 048} & \multirow{3}{*}{$\begin{array}{l}\text { H1c2 } \\
\text { Kabul }\end{array}$} \\
\hline & Öğretme & Fakülte & 409 & 4,5650 & & & \\
\hline & Süreci & Lisansüstü & 33 & 4,4576 & & & \\
\hline & \multirow{3}{*}{ İletişim } & Ön Lisans & 67 & 4,8358 & \multirow{3}{*}{, 781} & \multirow{3}{*}{,458 } & \multirow{3}{*}{$\begin{array}{l}\text { H1c- } \\
\text { 3Red }\end{array}$} \\
\hline & & Fakülte & 409 & 4,7819 & & & \\
\hline & & Lisansüstü & 33 & 4,7364 & & & \\
\hline & \multirow{3}{*}{$\begin{array}{l}\text { Davranış } \\
\text { Yönetimi }\end{array}$} & Ön Lisans & 67 & 4,3408 & \multirow{3}{*}{1,934} & \multirow{3}{*}{, 046} & \multirow{3}{*}{$\begin{array}{l}\text { H1c4 } \\
\text { Kabul }\end{array}$} \\
\hline & & Fakülte & 409 & 4,4686 & & & \\
\hline & & Lisansüstü & 33 & 4,4444 & & & \\
\hline & \multirow{3}{*}{ Motivasyon } & Ön Lisans & 67 & 4,7441 & \multirow{3}{*}{,699 } & \multirow{3}{*}{,498 } & \multirow{3}{*}{$\begin{array}{l}\text { H1c- } \\
\text { 5Red }\end{array}$} \\
\hline & & Fakülte & 409 & 4,6874 & & & \\
\hline & & Lisansüstü & 33 & 4,6364 & & & \\
\hline
\end{tabular}

H1c1: Sınıfın fiziksel düzeni, öğretmenlerin öğrenim durumlarına göre farkl111k gösterir.

H1c2: Öğrenme-öğretme süreçleri, öğretmenlerin öğrenim durumlarına göre farkl11ık gösterir.

H1c3: İletişimin etkinliği, öğretmenlerin öğrenim durumlarına göre farklılık gösterir.

H1c4: Davranış yönetimi becerisi, öğretmenlerin öğrenim durumlarına göre farkl111k gösterir.

H1c5: Motivasyon sağlama becerisi, öğretmenlerin öğrenim durumlarına göre farklıl1k gösterir. 
Çalışmada seçilen örneklemden elde edilen veriler yardımıyla sınıf yönetimi becerilerinin, öğrenim durumuna bağlı gösterdiği değişiklikler one way anaova testi yardımıyla incelenmiştir. Uygulanan one way anaova testi sonucunda elde edilen sonuçlar incelendiğinde öğretmenlerin sınıf yönetimi becerilerinden; sınıfın fiziksel düzeni $(p=0,699)$, iletişimin etkinliği $(p=0,458)$ ve motivasyon sağlama becerisi $(\mathrm{p}=0,498)$ için $\mathrm{H} 1 \mathrm{c} 1, \mathrm{H} 1 \mathrm{c} 3$ ve H1c5 hipotezlerinin reddedildiği ve öğrenim durumuna göre farkl11ık göstermediği tespit edilmiştir $(\mathrm{p}>0,05)$.

Öğretmenlerin sınıf yönetimi becerilerinden; öğrenme-öğretme süreci $(\mathrm{p}=0,48<0,05)$ ve davranış yönetimi becerisi $(\mathrm{p}=0,46<0,05)$ ile katılımc1ların arasında öğrenim durumuna göre istatistik açıdan farklılık olduğu tespit edilmiş ve H1c2, H1c4 hipotezleri kabul edilmiştir $(\mathrm{p}<0,05)$. Ön lisans düzeyinde eğitim almış öğretmenlerin davranış yönetiminde daha düşük, öğrenme-öğretme süreçlerinde ise daha yüksek puan ortalamalarına sahip olduğu gözlemlenmiştir.

\subsection{Sınıf Yönetimi Becerilerinin Hizmet Süresine Göre Değişimi}

Tablo 6. Hizmet Süresi ile Sınıf Yönetimi Becerileri Arasındaki İlişki İçin One Way Anaova Testi Sonuçları

\begin{tabular}{|c|c|c|c|c|c|c|c|}
\hline \multirow{16}{*}{ 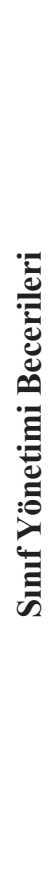 } & Düzeyler & $\begin{array}{l}\text { Hizmet } \\
\text { Süresi }\end{array}$ & $\mathbf{N}$ & Ort. & f Değeri & p Değeri & Hipotez \\
\hline & \multirow{5}{*}{$\begin{array}{l}\text { Sinıfin } \\
\text { Fiziksel } \\
\text { Düzeni }\end{array}$} & 0-4 Y11 & 137 & 4,3844 & \multirow{5}{*}{2,108} & \multirow{5}{*}{,039 } & \multirow{5}{*}{$\begin{array}{l}\text { H1d1 } \\
\text { Kabul }\end{array}$} \\
\hline & & 5-9 Y 11 & 118 & 4,5480 & & & \\
\hline & & 10-14 Y1l & 130 & 4,3949 & & & \\
\hline & & 15-19 Yil & 63 & 4,4497 & & & \\
\hline & & $20 \mathrm{Y}_{11+}$ & 61 & 4,5246 & & & \\
\hline & \multirow{5}{*}{$\begin{array}{l}\text { Öğrenme- } \\
\text { Öğretme } \\
\text { Süreci }\end{array}$} & 0-4 Y1l & 137 & 4,5832 & \multirow{5}{*}{,406 } & \multirow{5}{*}{,804 } & \multirow{5}{*}{ H1d 2 Red } \\
\hline & & 5-9 Y1l & 118 & 4,5831 & & & \\
\hline & & 10-14 Y1l & 130 & 4,5292 & & & \\
\hline & & 15-19 Yil & 63 & 4,5349 & & & \\
\hline & & $20 \mathrm{Y}_{11+}$ & 61 & 4,5902 & & & \\
\hline & \multirow{5}{*}{ İletişim } & 0-4 Y1l & 137 & 4,7723 & \multirow{5}{*}{, 355} & \multirow{5}{*}{, 840} & \multirow{5}{*}{ H1d3 Red } \\
\hline & & 5-9 Y1l & 118 & 4,7746 & & & \\
\hline & & 10-14 Yil & 130 & 4,7762 & & & \\
\hline & & 15-19 Y 11 & 63 & 4,8127 & & & \\
\hline & & $20 \mathrm{Y}_{11+}$ & 61 & 4,8328 & & & \\
\hline
\end{tabular}




\begin{tabular}{|c|c|c|c|c|c|c|}
\hline \multirow{5}{*}{$\begin{array}{l}\text { Davranış } \\
\text { Yönetimi }\end{array}$} & 0-4 Y1l & 137 & 4,4574 & \multirow{5}{*}{,532 } & \multirow{5}{*}{,712 } & \multirow{5}{*}{ H1d4Red } \\
\hline & 5-9 Y 11 & 118 & 4,4068 & & & \\
\hline & 10-14 Y1l & 130 & 4,4410 & & & \\
\hline & 15-19 Y1l & 63 & 4,5132 & & & \\
\hline & $20 \mathrm{Y} 11+$ & 61 & 4,4727 & & & \\
\hline \multirow{5}{*}{ Motivasyon } & 0-4 Y1l & 137 & 4,6799 & \multirow{5}{*}{,270 } & \multirow{5}{*}{,897 } & \multirow{5}{*}{ H1d5Red } \\
\hline & 5-9 Y 11 & 118 & 4,7046 & & & \\
\hline & 10-14 Y1l & 130 & 4,6659 & & & \\
\hline & 15-19 Yil & 63 & 4,7098 & & & \\
\hline & $20 \mathrm{Y}_{11}+$ & 61 & 4,7283 & & & \\
\hline
\end{tabular}

H1d1: Sınıfın fiziksel düzeni, öğretmenlerin hizmet süresine göre farklılık gösterir.

H1d2: Öğrenme-öğretme süreçleri, öğretmenlerin hizmet süresine göre farkl111k gösterir.

H1d3: İletişimin etkinliği, öğretmenlerin hizmet süresine göre farkl1lık gösterir.

H1d4: Davranış yönetimi becerisi, öğretmenlerin hizmet süresine göre farkl111k gösterir.

H1d5: Motivasyon sağlama becerisi, öğretmenlerin hizmet süresine göre farklılık gösterir.

Çalışmada seçilen örneklemden elde edilen veriler yardımıyla sınıf yönetimi becerilerinin hizmet süresine bağlı gösterdiği değişiklikler için one way anaova testi yapılmıştır. Uygulanan analizler sonucunda; öğrenme-öğretme süreci $(\mathrm{p}=0,804, \mathrm{H} 1 \mathrm{~d} 2)$, iletişimin etkinliği ( $\mathrm{p}=0,840, \mathrm{H} 1 \mathrm{~d} 3)$, davranış yönetimi becerisi $(p=0,712, H 1 d 4)$ ve motivasyon sağlama becerisi $(p=0,897, \mathrm{H} 1 \mathrm{~d} 5)$ hipotezlerinin reddedildiği ve öğretmenlerin hizmet süresine göre farkl1lık göstermediği tespit edilmiştir ( $\mathrm{p}>0,05)$.

Sınıfın fiziksel düzeni $(\mathrm{p}=0,039)$ için H1d1 hipotezinin kabul edildiği ve öğretmenlerin hizmet süresine göre farklılık gösterdiği tespit edilmiştir $(p<0,05)$. Ortalamalar incelendiğinde sınıfın fiziksel düzeni 0-4 yıl ve 10-14 y1l arasında hizmet süresi olan kişilerde daha düşük seviyede olduğu gözlenmiştir.

\section{Tartışma ve Sonuç}

$\mathrm{Bu}$ çalışma için katılımcı öğretmenlerin demografik veri dağılımları incelendiğinde; katılımcı öğretmenlerin neredeyse tamamının kadınlardan oluştuğu görülmektedir. Bu duruma bakılarak meslekteki kadın çalışan sayısının fazla olduğu ya da çalışmanın kadın yoğunluklu bir araştırma olduğu söylenebilir. Katılımcı 
öğretmenlerin büyük çoğunluğunun evli ve lisans mezunu olduğu tespit edilmiştir. Dolayısıyla öğretmenlerin kariyer ilerlemesi yapabilmeleri ve kendilerini geliştirebilmeleri için lisansüstü eğitimlere teşvik edilmeleri yararlı olabilir.

Cinsiyet ile sınıf yönetimi becerileri arasındaki ilişki için t-testi sonucunda; kadın öğretmenlerin motivasyon açısından erkek öğretmenlere göre daha farklı değere sahip olduğu görülmektedir. Bu durumun erkek öğretmenlerin meslekten beklentilerini karşılayamamasına ve bu durumda sınıf içi sorumluluklarına etki etmesine sebep olabilir. Kadın öğretmenlerin annelik içgüdüsü, saygınlık ve takdir edilme gibi beklentilerinin karşılanması bu meslekteki motivasyonlarının artmasına neden olabilir. Zembat, vd., (2017)'nin çalışmasında “sınıf yönetimi beceri düzeyleri” karşılaştırılmış, kadın öğretmenlerin erkek öğretmenlere göre daha yüksek beceri düzeylerine sahip oldukları ayrıca meslek beklentilerinin daha fazla olduğu belirtilmiştir. Araştırmanın bulgularına göre, sınıf yönetiminde öğrenme-öğretme süreçleri, iletişimin etkinliği ve davranış yönetimi becerisi ile öğretmenlerin cinsiyet değişkenine göre anlamlı bir farkl11ık ortaya çıkmamıştır ${ }^{39}$.

Bu çalışmada, medeni durum ile sınıf yönetimi becerileri arasındaki ilişki için t-testi sonuçlarına bakıldığında, öğretmenlerin sınıf yönetimi becerilerinin sınıfın fiziksel düzeni, öğrenme süreçleri, iletişimin etkinliği, davranış yönetimi becerisi ve motivasyon sağlama becerisi boyutlarında anlamlı bir farklılık görülmüştür. Araştırmanın bu bulgusu, İlgar (2007)'ın ilköğretim öğretmenleri üzerinde yaptığ1 çalışmanın bulgusuyla örtüşmemektedir. İlgar (2007)'a göre öğretmenlerin "medeni durum" ile "sınıf yönetimi becerileri" arasında evli öğretmenlerin bekâr öğretmenlere göre daha yüksek becerileri düzeyine sahip oldukları ifade edilmiştir. Evli veya bekâr olması fark etmeksizin öğretmenlerin aldıkları mesleki eğitimleri sorunsuz bir şekilde uyguladıkları belirtilmiş̧ir. Evli olmanın getirdiği geçim kaygıSı, çocuk sahibi olmanın beraberinde getirdiği çocuğa zaman ayırma, ihtiyaçlarını karşılamak için maddi sıkıntılar, gelecek kaygısı gibi problemler; bekâr olmanın getirdiği yalnız olma stresi, çevre baskısı ve tek başınalığın getirdiği maddi sorunlar gibi problemlerin öğretmenlerin mesleklerine yansıdığ 1 ancak evli veya bekâr öğretmenlerin yaşamlarında bazı olumsuzluklar olsa da, mesleklerini iş ahlâkına uygun ve bilinçli bir şekilde gerçekleştirdikleri ifade edilmiştir ${ }^{40}$.

39 R. Zembat - H. İ. Tunçeli - E. A. Yavuz, "Okul Öncesi Öğretmenlerinin Sınıf Yönetimi Becerileri ile Problem Çözme Becerileri Arasındaki İlişkinin İncelenmesi”, Ahi Evran Üniversitesi Kırşshir Eğitim Fakültesi Dergisi, cilt 18, sayı 3, 2017, s. 40.

40 L. İlgar, "İlköğretim Öğretmenlerinin Sınıf Yönetimi Becerileri Üzerine Bir Araştırma", (Yayımlanmamış Doktora Tezi), İstanbul Üniversitesi Sosyal Bilimler Enstitüsü, İstanbul, 2007, s. 32. 
Öğrenim durumu ile sınıf yönetimi becerileri arasındaki ilişkinin incelenmesi için one way anaova testi sonuçları incelendiğinde; öğretmenlerin, öğrenmeöğretme süreci ve davranış yönetimi becerisi boyutlarında anlamlı bir farklılık görülürken, sınıfın fiziksel düzeni, iletişimin etkinliği, ve motivasyon sağlama becerisi boyutlarında anlamlı farklılık olmadığı ortaya çıkmıştır. Bu bağlamda öğretmenlerin öğrenim durumu ne olursa olsun aldıkları mesleki eğitim sayesinde sınıf yönetimi becerilerinin benzer düzeylerde olduğu söylenebilir. Araştırmaya göre okul öncesi öğretmenlerinin sahip oldukları eğitim düzeyi sınıf yönetimi becerilerinde bir farklılaşmaya sebebiyet vermemiştir. Yani öğretmenlerin eğitim düzeyine bağlı kalmaksızın mesleki profesyonelliklerini korudukları ve eğitim durumunun sınıf yönetimi becerileri için ayırıcı ve belirleyici bir etken olmadığg söylenebilir. Öğretmenlerin mesleki eğitim aldıkları süre mesleki bilgiler ve mesleki tecrübe için büyük önem arz arzedebilir. Bir konu üzerinde alınacak eğitimin geniş bir zamana yayılması ve daha detaylı ele alınması, bu alanda öğrenilecek bilgilerin daha iyi bir şekilde özümsenmesinde ve içselleştirilmesinde önemli bir rol oynayabilir. Öğretmenlerin davranış yönetimi becerisi eksikliğinin nedenlerinden bir tanesi aldıkları hizmet içi eğitimlerin yeterli olmamasından kaynaklanabilir. Koçoğlu (2013)'nun yaptığı çalışmada ise; "okul öncesi öğretmenlerinin sınıf yönetimi becerilerinin" sınıf yönetimiyle ilgili eğitimler alıp almama durumuna göre farklılık göstermediği ifade edilmiştir ${ }^{41}$. Ayrıca Durgun (2010)'un çalışmasında, "sınıf yönetimi”" alanında alınan eğitimlerin önemli olduğu vurgulanmış ve öğretmenlerin "sınıf yönetimi” becerilerinin geliştirmesiyle ilgili eğitimlerin teorik ve özellikle uygulamalı olarak yapılmasının faydalı olduğu belirtilmiştir ${ }^{42}$.

Araştırmada ortaya çıkan bir diğer sonuç ise öğretmenlerin hizmet süresi ile sınıf yönetimi becerileri kapsamında öğrenme-öğretme süreçleri, iletişimin etkinliği, davranış yönetimi becerisi ve motivasyon sağlama becerisi boyutlarında anlamlı farklılık görülmediği tespit edilmiştir. Bu bağlamda öğretmenlerin hizmet süresi fark etmeksizin, aldıkları mesleki eğitim ve stajlar sayesinde sınıf yönetimi becerilerinin geliştirilebileceği önerilebilr. Öğretmenlerin aldıkları eğitim ve iş tecrübeleri sayesinde mesleğe başladıkları ilk yıllarda bile zorluk çekmeden gö-

41 A. M. Koçoğlu, "İlkokullardaki Sınıf Öğretmenlerinin Sınıf Yönetimi Becerilerinin Çok Boyutlu Olarak İncelenmesi (İstanbul ili Sancaktepe Örneği)", (Yayımlanmamış Yüksek Lisans Tezi), Yeditepe Üniversitesi Sosyal Bilimler Enstitüsü, İstanbul, 2013, s. 70.

42 B. Durğun, "Sınıfında Kaynaştırma Öğrencisi Bulunan Sınıf Öğretmenlerinin, Sınıf Yönetimi Becerilerinin Çeşitli Değişkenler Açısından İncelenmesi (Sancaktepe İlçesi Örneği)", (Yayımlanmamış Yüksek Lisans Tezi), Yeditepe Üniversitesi Sosyal Bilimler Enstitüsü, İstanbul, 2010, s. 22. 
revlerini yerine getirebildikleri görülebilmektedir. Bu bağlamda mesleki eğitimler verilirken uygulamalı derslerin değerinin bilinmesi büyük önem arz etmektedir. Sınıf yönetimi becerileri değişkenlerinden birisi olan sınıfın fiziksel düzeni, öğretmenlerin hizmet süresine göre farkl1lık göstermektedir. Hizmet y1lı az olan öğretmenlerin sınıf düzenini kontrol etme ve düzenlemede daha az ilgili olduğu görülmektedir. Meslek hayatının ilk yıllarında öğretmenler daha çok verecekleri eğitime odaklanabilir ve bu durum sınıfin fiziksel düzeninden kaynaklanacak bir takım problemlere neden olabilir. Öğretmenlerin mesleki tecrübesi ve deneyimleri arttıkça bu sınıf düzeninden kaynaklanabilecek problemler ön görülerek gerekli önlemler alınarak problem yaşamamak mümkündür. Söylemez (2008)'in, yaptığ 1 araştırma sonuçlarına göre öğretmenlerin mesleki deneyimlerinin "sınıf yönetimi becerileri” üzerinde etkili olduğu gözlemlenmiştir ${ }^{43}$.

Sınıf yönetimi beceri düzeylerinin geliştirilmesine öneri olarak; öğretmenlerin sınıf yönetimi ile ilgili beceri düzeylerinin nasıl arttırılabileceği, desteklenmesi, nelerin yararlı olabileceği, sınıfların fiziksel yapısının nasıl olması gerektiği ve yapılacak eğitim etkinliklerin nasıl yapılmasının gerektiği konularında sürekli yenilikler ve araştırmalar yapılması önemli faydalar sağlayabilir. Bundan sonra yapılacak araştırmalar, daha geniş bir evrende örneğin il veya ülke bazında resmi ve özel ilkokulların tamamında yapılabilir.

43 Ö. Z. Söylemez, "İşitme Engelli Okullarında Çalışan Öğretmenlerin Empati Eğilimleri İle Sınıf Yönetim Becerileri Arasındaki İlişkik”, (Yayımlanmamış Yüksek Lisans Tezi), Yeditepe Üniversitesi Sosyal Bilimler Enstitüsü, İstanbul, 2008, s. 44. 


\section{Kaynakça}

Akgün, E. - Yarar, M. - Dinçer, Ç., "Okul Öncesi Öğretmenlerin Sınıf İçi Etkinliklerde Kullandıkları Sınıf Yönetimi Stratejilerinin İncelenmesi”, Pegem Ĕ̈itim ve Öğretim Dergisi, cilt 1, say1 3, 2011.

Akın, U. - Koçak, R., "Öğretmenlerin Sınıf Yönetimi Becerileri ile İş Doyumları Arasındaki İlişki”, Educational Administration: Theory and Practice, say1 51, 2007.

Akpınar, O. - Öz, F. S., “Gerçeklik Terapisi: Özellikler, Temel Kavramlar, Tedavi, Uygulama ve Değerlendirme", Electronic Journal of Social Sciences, cilt 12, say1 43, 2013.

Aydın, A., Sınıf Yönetimi, 20. bs., Ankara, Pegem Akademi Yayınları, 2019.

Balat, G. U., "Sınıf Yönetimi Kavramı ve Sınıf Yönetimi Modelleri”, Okul Öncesi Eğitimde Sinıf Yönetimi, (içinde), ed. G. U. Balat, Ankara, Eğiten Kitap, 2013.

Başar, H., Sınıf Yönetimi, İstanbul, Milli Eğitim Bakanlığı Yayınları, 1999.

Bayraktar, H. V., "Sınıf Yönetiminde Öğrenci Motivasyonu ve Motivasyonu Etkileyen Etmenler", International Periodical For TheLanguages, Literature and History of Turkish or Turkic, cilt 10, say1 3, 2015.

Bircan, H. - İskender, G., "İş Ölçümü Tekniklerinden Zaman Etüdü Üzerine Bir Uygulama”, C.Ü. İktisadi ve İdari Bilimler Dergisi, cilt 6, say1 2, 2005.

Büyüköztürk, Ş. - Çakmak, E. K. - Akgün, Ö. E. - Karadeniz, Ş. - Demirel, F., Bilimsel Araştırma Yöntemleri, 25. bs., Ankara, Pegem Akademi Yayınları, 2017.

Büyüköztürk, Ş., Sosyal Bilimler için Veri Analizi El Kitabı, Ankara, Pegem A Yayınc1lik, 2007.

Çakmak, M., "Öğretmen Adaylarının Sınıf Yönetimi Stratejilerine Yönelik Görüşleri”, Hacettepe Üniversitesi Eğitim Fakültesi Dergisi, say1 35, 2008.

Çelik, K., "Disiplin Oluşturma ve Kuram Geliştirme", Etkili Sinıf Yönetimi, (içinde), ed. H. Kıran, Ankara, Anı Yayıncılık, 2007.

Çelikkaleli, Ö. - İnand1, Y., "İlköğretim Öğretmenlerinde Disiplin Anlayışı ve Kişilerarası İlişkiye Yönelik Yetkinlik İnancının İncelenmesi”, Pegem Eğitim ve Öğretim Dergisi, cilt 2, say1 2, 2012.

Çetinkaya, Z., "Türkçe Öğretmen Adaylarının İletişim Becerilerine İlişkin Görüşlerinin Belirlenmesi”, Kastamonu Eğitim Dergisi, cilt 19, sayı 2, 2011. 
Durğun, B., "Sınıfında Kaynaştırma Öğrencisi Bulunan Sınıf Öğretmenlerinin, Sınıf Yönetimi Becerilerinin Çeşitli Değişkenler Açısından İncelenmesi (Sancaktepe İlçesi Örneği)", (Yayımlanmamış Yüksek Lisans Tezi), Yeditepe Üniversitesi Sosyal Bilimler Enstitüsü, İstanbul, 2010.

Edwards, C. H. - Watts, V. J., Classroom Discipline \& Management: an Australasian Perspective, Australia, Milton, Wiley, 2004.

Ekici, G., "Sınıf Yönetimi Dersinin Öğretmen Adaylarının Öğretmen Öz-Yeterlik Algı Düzeyine Etkisi”, Hacettepe Üniversitesi Eğitim Fakültesi Dergisi, cilt 35, 2008.

Erden, M., Sinıf Yönetimi, Ankara, Arkadaş Yayınevi, 2005.

Ergen, Y., "Sınıf Öğretmenlerinin Sınıf Yönetim Becerileri, Akademik İyimserlikleri ve Mesleki Bağlılıkları Arasındaki İlişki", (Yayımlanmamış Doktora Tezi), Ondokuz Mayıs Üniversitesi Eğitim Bilimleri Enstitüsü, Samsun, 2013.

Gordon, T., Etkili Öğretmenlik Ĕgitimi, çev. E. Aksoy, İstanbul, Sistem Matbaacilik, 1974.

Güney, S., İnsan Kaynakları Yönetimi, 2. bs., İstanbul, Nobel Akademik Yayınları, 2015.

Gürsel, M., Sınıf Yönetimi, Yenilenmiş 3. bs., Konya, Eğitim Akademi Yayınlar1, 2011.

Gürşimşek, I., "Etkin Sınıf Yönetimi İçin Etkili İletişim Becerileri”, Eğitim ve Bilim, cilt 23, say1 112, 1999.

İlgar, L., "İlköğretim Öğretmenlerinin Sınıf Yönetimi Becerileri Üzerine Bir Araştırma", (Yayımlanmamış Doktora Tezi), İstanbul Üniversitesi Sosyal Bilimler Enstitüsü, İstanbul, 2007.

Kapusuzoğlu, Ş., "Okul Öncesi Sınıf Yönetimi Uygulamalarıyla Aile Tutumunun Çocuğun Gelişim Özelliklerine Etkisinin Değerlendirilmesi”, Abant İzzet Baysal Üniversitesi Sosyal Bilimler Enstitüsü Dergisi, cilt 2, say1 12, 2006.

Koçoğlu, A. M., "İlkokullardaki Sınıf Öğretmenlerinin Sınıf Yönetimi Becerilerinin Çok Boyutlu Olarak İncelenmesi (İstanbul ili Sancaktepe Örneği)", (Yayımlanmamış Yüksek Lisans Tezi), Yeditepe Üniversitesi Sosyal Bilimler Enstitüsü, İstanbul, 2013.

Okutan, M., Sinıf Yönetiminde Örnek Olaylar, Ankara, Öğreti-Pegem Akademik Yayınc1lık, 2004.

Özdemir, M. Ç., Sınıf Yönetimi, Ankara, Pegem Atıf İndeksi, 2017. 
Özgün, U. - Kandır, A., "Okul Öncesi Dönemde Erken Akademik Beceriler”, Kuramsal Ë̆itimbilim Dergisi, cilt 3, say1 2, 2010.

Özkan, H. H., "Öğrenme Öğretme Modelleri Açısından Modüler Öğretim”, Atatürk Üniversitesi Sosyal Bilimler Enstitüsü Dergisi, cilt 6, say1 2, 2005.

Paliç, G. - Keleş, E., "Sınıf Yönetimine İlişkin Öğretmen Görüşleri”, Educational Administration: Theory and Practice, cilt 17, say1 2, 2011.

Söylemez, Ö. Z., "İşitme Engelli Okullarında Çalışan Öğretmenlerin Empati Eğilimleri ile Sınıf Yönetim Becerileri Arasındaki İlişki”, (Yayımlanmamış Yüksek Lisans Tezi), Yeditepe Üniversitesi Sosyal Bilimler Enstitüsü, İstanbul, 2008.

Sucuoğlu, B., "Okul Öncesi Sınıflarda Kaynaştırma ve Sınıf Yönetimi”, Çoluk Çocuk Dergisi, sayı 40, 2008.

Şahin, F. T. - Kalburan, F. N. C., "Aile Eğitim Programları ve Etkililiği: Dünyada Neler Uygulanıyor?”, Pamukkale Üniversitesi Eğitim Fakültesi Dergisi, cilt 1, say1 25, 2009.

T.C. Yükseköğretim Kurulu, Türkiye Yükseköğretim Ulusal Yeterlikler Çerçevesi (TYUYÇ) : Ara Raporu, 2009.

Terzi, A. R., "Sınıf Yönetimi Açısından Etkili Öğretmen Davranışları", Milli Ĕgitim Dergisi, sayı 155, 2002.

Topses, G., "Öğrenci Davranışlarını Etkileyen Psikolojik Etmenler ve Sorunlar”, Sınıf Yönetimi, (içinde), ed. Leyla Küçükahmet, 9. bs., Ankara, Nobel Yayın Dağıtım, 2007.

Yaman, B., "Pedagojik Formasyon Eğitimi Almamış Öğretmenlerin Sınıf Yönetimi Algıları / Aksaray ili Örneği”, Elektronik Sosyal Bilimler Dergisi, cilt 9, say1 31, 2010,.

Yazıcıŏlu, Y. - Erdoğan, S., SPSS Uygulamalı Bilimsel Araştırma Yöntemleri, Ankara, Detay Yayınc1lık, 2004.

Yeşilyurt, E. - Çankaya, İ., "Sınıf Yönetimi Açısından Öğretmen Niteliklerinin Belirlenmesi”, Elektronik Sosyal Bilimler Dergisi, cilt 7, say1 23, 2008.

Yüksel, Ö., Girişimciler İçin İşletme Yönetimi, Ankara, Gazi Yayınları, 2003.

Zembat, R. - Tunçeli, H. İ. - Yavuz, E. A., “Okul Öncesi Öğretmenlerinin Sınıf Yönetimi Becerileri İle Problem Çözme Becerileri Arasındaki İlişkinin İncelenmesi”, Ahi Evran Üniversitesi Kırşehir Eğitim Fakültesi Dergisi, cilt 18, say1 3, 2017. 
Zontul, M. - Mert, C. A., "Sınıf İçi Davranış Problemlerinin Çözümünde Davranış Yönetim Sisteminin Etkisi”, Eğitim ve Öğretim Araştırmaları Dergisi, cilt 4, say1 4, 2015.

\section{Araştırmacıların Katkı Oranı}

Araştırmanın her aşamasından yazar sorumludur.

\section{Çatışma Beyanı}

Araştırmada herhangi bir çıkar çatışması bulunmamaktadır. 
